\title{
The Roles of Islamic Education Teachers Strategy in Embedding Multicultural Values
}

\author{
Arif Anas ${ }^{1 *}$,Askar Askar 2, and Hamlan Hamlan ${ }^{3}$ \\ ${ }^{1}$ Islamic Education Department, Postgraduate, Institut Agama Islam Negeri Palu \\ ${ }^{2}$ Islamic Education Department, Postgraduate, Institut Agama Islam Negeri Palu \\ ${ }^{3}$ Islamic Education Department, Postgraduate, Institut Agama Islam Negeri Palu
}

\section{ABSTRACT}

The objective of the paper is to find out the strategy of Isalamic education teachers in embedding multicultural values at a senior high school in Palu. The study used a qualitative case study method. Data were gathered through direct observation, undepth interviews with the school's teachers, and written material analyses. This study found that the teachers of the school embedded multicultural values through humanistic approach in taching and daily school's interaction. Students were given tolerance understanding to respect religion and ethnicity differences. The curriculum of the school was also redusugned by integrating multicultural values. Intolerance attitudes were strongy prohibited and stric rules to respect each other were imposed. Islamic education teachers were imposed to teached moderate Islamic teachings which respect multicultural values. Radical Islamic views were prohibited to teach in the school. Muslim and non-Muslim students were treated equally regarding their views and beliefs.

\section{ARTICLE \\ INFORMATION}

Keywords:

Islamic education, teachers, multicultural values 


\section{Introduction}

The Indonesian nation has various customs with various races, ethnicities, religions, and languages. "Indonesia is one of the largest multicultural countries in the world." The wealth and diversity of religions, ethnicities, and cultures are like a double-edged sword. On the one hand, this wealth is a treasure that should be preserved and provides nuances and dynamics for the nation and can also be a starting point for disputes, vertical and horizontal conflicts. This diversity is recognized or not, and many raise problems as seen today. The inability of individuals in Indonesia to accept these differences has a negative effect.

Understanding multicultural diversity means accepting the diversity of cultural expressions that contain human values and beauty. For this reason, it is appropriate that the insight of multiculturalism is grounded in the world of education today. The insight of multiculturalism is critical, especially in fostering a sense of national unity and integrity in accordance with the spirit of the independence of the Republic of Indonesia in 1945 as a milestone in the history of the establishment of the Unitary State of the Republic of Indonesia (NKRI). Thus, multi-ethnic education, in fact, makes multiculturalism learning based on Bineka Tunggal Ika, the dominance of the majority culture inherited from the perception and management of Bineka Tunggal Ika that was not appropriate in the past has an impact on various aspects of Indonesian people's lives today.

The lack of a comprehensive understanding of multiculturalism actually causes the moral degradation of the younger generation. Attitudes and behaviors that appear are often unsympathetic, even very contrary to the noble cultural values of their ancestors. Attitudes such as togetherness, respect for others, and mutual cooperation begin to fade. The existence of arrogance due to the dominance of the majority culture causes a lack of understanding in interacting with culture and with other people. ${ }^{1}$

Multicultural education provides hope in overcoming various societal upheavals, such as racial and ethnic disputes that occur in several areas. ${ }^{2}$ Multicultural education is education that always upholds values, beliefs, and diversity, regardless of aspects of society. Therefore, the cultivation of multicultural values must be instilled at every level of education and involve various community structures in shaping students' character. Especially in understanding and mutual respect between various tribes, so that they become a contribution in the effort to transform the values and characters of

${ }^{1}$ Rosita Endang Kusmariani, Pendidikan Multikultural sebagai Alternatif Penanaman Nilai Moral dalam Keberagaman. Jurnal Paradigma , edisi 2 Tahun 2006, 50.

2 Rusli, Rusli. (2009). Gagasan Khaled Abu Fadl tentang "Islam Moderat" versus "Islam Puritan" (Perspektif Sosiologi Pengetahuan). Jurnal Ilmiah Ilmu Ushuluddin, 8(1), 99-123.

e-ISSN: 2715-4572

p-ISSN: 2716-1439 
local culture that are insightful and Nationalism.

Education has an important role in shaping public life, but it is also believed to be able to play a significant role in shaping politics and culture. Thus education as a medium for preparing and social life and will become the basis of educational institutions that are required for idealistic values. ${ }^{3}$

The strategy and role of teachers are essential factors in implementing inclusive and moderate values of diversity (as suggested by multicultural education) in schools. Teachers have an essential role in multicultural education because they are one of the targets of this educational strategy.

Islamic religious education with a multicultural perspective is considered to accommodate cultural equality that can reduce vertical and horizontal conflicts in a heterogeneous society where the demand for recognition of the extension and uniqueness of culture, ethnic groups is very common. ${ }^{4}$ Therefore, an Islamic religious education teacher is expected to understand and implement and instill multicultural values in his duties so as to give birth to a civilization of tolerance, democracy, tolerance, justice, harmony, and other human values. Thus, if you want to

${ }^{3}$ M. Agus Nuryatno, Mazhab Pendidikan Kritis Menyikap Pengetahuan, Politik dan kekuasaan (Resist Book, Yogyakarta: 2008), 81

4 Pribadi, Mohammad, \& Nurdin, Nurdin. (2021). The Practice of Salawat Nariyah in Rural Javanese Society Indonesia: Religiosity or Sociality? Review of International Geographical Education Online, 11(5), 2545-2555. overcome all the problems of society, starting from a systematic and methodological arrangement in education, as one component in learning to improve the reality of society, it is necessary to start from a multicultural learning process that is formed using multicultural-based learning. Where the learning process is more directed to efforts to appreciate the differences between fellow human beings so that peace and tranquility are realized in the order of community life, therefore, the educational process in schools must also instill multicultural values.

\section{Literature review}

\subsection{Islamic Education and the Concept of Multicultural Values}

The term Multiculture comes from the West, which was developed and spread to the third world or developing countries. This ideology is a popular ideology in the West, namely a policy and attitude to treat everyone fairly. As happened in Australia, those who previously oppressed one particular ethnicity, through the socialization and application of this ideology, were able to have a positive impact, namely providing justice to all adherents of the culture. In addition, this understanding is a new policy response to diversity.

In other words, simply understanding the existence of different communities is not enough because the most important thing is that these communities are treated equally by the state or one community to another. Therefore, multiculturalism as a movement demands recognition

e-ISSN: 2715-4572

p-ISSN: 2716-1439 
(politics of recognition) of all differences as identities in a society that must be accepted, respected, protected, and their existence guaranteed. 5

Multiculturalism is a relatively new understanding compared to other ideologies. Emergence around the decade or the 70s, for example, in Canada, England and America. The Canadian government issued a policy on multiculturalism in 1965. In England, multiculturalism was only developed in 1998, while in America, multiculturalism was carried out by left-radical circles to criticize the policies of europacentrism. ${ }^{6}$

This understanding is motivated by efforts to eliminate racial discrimination between whites and blacks in America and Canada. After being coupled with democratic values, this effort is more successful in maintaining the integration and unity of the nation. In fact, according to them and indeed can be witnessed by the citizens of the world, the success of Barack H Obama (black) as President of America with a majority of the white population can be used as an illustration. So, multiculturalism recognizes the diversity of culture, ethics, and religion.

The United States, when it wanted to form a new society after its independence (July 4, 1776), realized that its society consisted of various races and origins from different countries.

${ }^{5}$ Rusli, Rusli. (2014). Teaching Usul alFiqh: A Multicultural Education Model. AlTahrir: Jurnal Pemikiran Islam, 14(2), 447-464.

6Zulhairi Misrawi, Al-Qur'an Kitab Toleransi: Inklusivisme, Pluralisme dan Multikultural, (Jakarta: Fitrah, 2007), 215-218
Therefore, in this case, America is trying to find a breakthrough by pursuing a strategy of becoming a school as a center for socializing and cultivating new values aspired.

Through the approach from elementary school to university. The United States succeeded in forming a nation that, in its development, surpassed its parent society, namely Europe. In relation to cultural values that need to be inherited and developed through the education system in a society, the United States uses a democratic system in education pioneered by John Dewey. The point is that tolerance is intended for the common good and respects trust and interacts with community members.

It must be realized together that the success of these Western countries takes a long time or history and applies different methods, methods, and strategies. For example, in America itself, this policy has been implemented for centuries, and only recently has it been declared successful. So are the UK, France, and Australia. Due to this truth claim, multicultural values are now being pushed to all levels of society in Indonesia, especially Muslims. ${ }^{7}$

These multicultural currents and waves have entered the territory of Indonesia. Many freelance writings in the mass media from PT/University experts talk about multicultural issues. According to the author's notes, Independence, which started earlier, has

${ }^{7}$ AGPAII, dkk, Panduan Integrasi Nilai Multikulutaral dalam Pendidikan Agama Islam Pada SMA dan SMK, (Jakarta: KIRANA CAKRA BUANA, 33-34 
even produced a book. A year ago, Submit Curriculum and Evaluation Diktis Kemenag RI held a workshop on this issue. Then AGPAII collaborated with the Tifa Foundation. The Rahimah Foundation and the Indonesian Ministry of Religion's Ditpais held workshops, including the integration of multicultural values in PAI subjects, including in this collaboration the preparation of Guidelines for the Integration of Multicultural Values of Islamic Religious Education in Schools. ${ }^{8}$

Through an overview of the history of the emergence of multiculturalism, we can fully understand this understanding and then be able to intelligently sort and choose multicultural existence so that with care and broad insight, we can apply multicultural values in PAI learning in schools. Individually or in the wider community.

In essence, multicultural values are not something new from the Islamic perspective. The emergence of Islam was not in a vacuum. At an early stage, the presence of Islam has faced social realities and various beliefs and religions. We must be sure that we are also aware that the Qur'an, in many respects, does not provide details. It is sufficient to lay out basic principles, including in the social activities of the nation and society. ${ }^{9}$

\section{Definition of Multicultural Values}

${ }^{8}$ Abdulrahman dkk, Profil Asosiasi Guru Pendidikan Agama Islam (AGPAII), (Jakarta: NISRINA, 2009), 2-5

${ }^{9}$ AGPAI dkk, Panduan Integrasi Nilai Multikulutaral., 35-36
Values are at the core of every culture. In this case, it includes moral values that regulate the rules in living together. ${ }^{10}$ Moral itself has experienced developments from an early age. A person's moral development is significant for students' personality and social development, for that moral education will more or less affect attitudes or behavior when interacting with other people. ${ }^{11}$

Education that focuses on multicultural education according to the concept, although none of the permanent concepts have been applied. In the concept of Paulo Freire (expert in liberation education), according to him, education is not an "ivory tower" that tries to stay away from social and cultural realities. Education must be able to create an educated and educated society, not a society that only glorifies social achievements as a result of the wealth and prosperity it experiences. ${ }^{12}$

According to James A Banks:

First, integrating various cultures and groups to illustrate basic concepts, generalizations, and theories in subjects/disciplines of science. Second, it brings students to understand the implications of culture in a subject (discipline). Third, adapting teaching methods

${ }^{10}$ Rusli, Rusli. (2020). The Role of Family in Preventing Social Conflict in Society From Islamic Perspectives. HUNAFA: Jurnal Studia Islamika, 17(1), 108-122.

11Haditono. S.R, Psikologi Perkembangan Pengantar dalam Berbagai Bagiannya, (Gadja Mada University Press. Yogyakarta: 2002), 168.

${ }^{12}$ Choirul Mahfud, Pendidikan Multikultural, (Pustaka elajar, Yokyakarta: 2006), 176-177.

e-ISSN: 2715-4572

p-ISSN: 2716-1439 
to the way students learn in order to facilitate the academic achievements of students who are diverse in terms of race, culture, or social. Fourth, identify the racial characteristics of students and determine their teaching methods. Then, train groups to participate in sports activities, interact with all staff and students of different ethnicities and races in an effort to create a tolerant and inclusive academic culture. ${ }^{13}$

Based on the above concept, multicultural education instills a respectful, sincere and tolerant way of life towards cultural diversity that lives in the midst of a plural society. Thus, multiculturalism is expected to have the resilience and mental flexibility of the nation in the face of social conflicts so that national unity is not easily divided.

This multicultural-based education will be able to instill the values of pluralism, humanism, and democracy directly in schools to students, especially for students to be able to design learning based on the diversity of abilities, students' social backgrounds, religion, culture, and others. This must be considered in the interpretation of strategies and concepts of multicultural education. The most important thing in this strategy is that students can easily understand the lessons learned and increase their awareness always to behave humanist pluralist, and democratic. ${ }^{14}$ Likewise, a teacher

13Ibid., 177-178.

14 Amiruddin, Amiruddin, Nurdin, Nurdin, \& Ali, Moh. (2021). Islamic Education masters the material professionally and must be able to instill the core values of multicultural education such as humanism, democracy, and pluralism. ${ }^{15}$

This condition is a challenge for the world of education to be more oriented towards multicultural understanding. Schools that have a strategic role in inculcating the nation's moral values are responsible for these efforts. Through the teaching process, schools need to emphasize and instill that diversity as a nation's wealth deserves to be understood comprehensively. In line with that, the attitude of plurality is an attitude of accepting plural and diverse situations in the hope that it can foster mutual understanding. Thus, a pluralist attitude is a construction of multicultural values that are instilled in the school environment. The cultivation of multicultural values in schools is an installation of trust (the cognitive component) and is expected to influence emotional (active) and behavioral (cognitive) problems, which will foster an initial positive attitude in students towards plural conditions. Between individuals, it is hoped that a sense of love, peace, and tranquility will begin to emerge in a pluralistic society. The indicators of a person who has a pluralist attitude are living in differences (tolerance), mutual respect, building mutual trust, interdependence (mutual

Teacher Communication Strategy in Increasing Students' Learning Interest. International Journal of Contemporary Islamic Education, 3(1), 41-61.

${ }^{15}$ Ainul Yaqin, Pendidikan Multikultural Cross-cultural Understanding untuk Demokrasi dan Keadiilan, (Pilar Media, Yogyakarta: 2005), 18.

e-ISSN: 2715-4572

p-ISSN: 2716-1439 
need/mutual dependence), appreciation of cultural plurality.

Diversity needs to be instilled from an early age so that the younger generation is able to have a more positive paradigm of thinking in viewing something "different" from itself. The hope is the establishment of a sympathetic attitude and moral behavior. Multicultural education is expected to be a solution to the problem of the nation's moral degradation.

The conclusion to understand the standard of multicultural values in the context of religious education, according to Zakiyuddin Baidhawy, there are several characteristics. These characteristics are: Learning to live in differences, building mutual trust, maintaining mutual understanding, upholding mutual respect, openmindedness, appreciation and independence, conflict resolution, and non-violent reconciliation. ${ }^{16}$

\subsection{Multicultural Values}

H.A.R Tilaar recommends multicultural values in general: learning to live in differences, building mutual trust, maintaining mutual understanding, upholding mutual respect, being open in thinking, appreciating and interdependence, conflict resolution, and reconciliation. Furthermore, the four core values of multicultural values mentioned in the previous discussion are: first, appreciation of the reality of cultural pluralism in society. Second, the

\footnotetext{
16Zakiyuddin Baidhawy, Pendidikan Agama Berwawasan Multikultural., 78-84.
}

recognition of human dignity and human rights. Third, the development of global community responsibility. Fourth, the development of human responsibility towards planet earth. ${ }^{17}$

While values, according to Daniel J Mueller (1992:6), are like attitudes, values also involve judgment. Social theorists generally agree that abstract values, structures, and structures are more than attitudes. It is further explained according to general agreement that values influence attitudes. Thus the value is a determinant of attitude. Of course, a single attitude, caused by many values or by a person's entire value system. ${ }^{18}$

All of the things mentioned above are also added the opinions expressed in the language of the vision and mission of multicultural education by always upholding and respecting pluralism, democracy, and humanism. Based on the opinion, the indicators for the implementation of multicultural values in schools are as follows:

Tolerance in Arabic can be interpreted tasamuah, which means an attitude of letting, graceful, generous, and like to give. So tolerance is respecting and respecting human rights. Freedom of belief in the sense that there is no compulsion in matters of religion, freedom of thought or opinion, freedom of assembly, and others. History records that the Messenger of Allah was not only able to find the two tribes of Aus and Khazraj who were always at war. But

${ }^{17}$ Maslikhah Quo Vadis, Pendidikan Multikutur, (STAIN Sala Tiga Jateng:JP Books, 2007), 70

${ }^{18} \mathrm{Ibid} .72$

e-ISSN: 2715-4572

p-ISSN: 2716-1439 
was able to apply the absence of coercion in religion against the people of Madina at that time. Khulafaur Rashidin then continued this tradition of tolerance after Prophet Muhammad died. ${ }^{19}$

\subsection{Definition of Multicultural Education}

Multicultural is cultural diversity. While etymology, the term multiculturalism is formed from the words multi (many), culture (culture), and ism (understanding/school). In essence, the word multiculturalism contains the recognition of the dignity of human beings who live in their own unique community and culture. ${ }^{20}$ Meanwhile, culture (culture) itself cannot be separated from four important themes, namely: religion (school), race (ethics), ethnicity, and culture. This implies that the multicultural discussion includes not only cultural differences but also includes the progress of religion, race, and ethnicity. ${ }^{21}$

Multiculturalism is also a concept where a community in the context of nationality can recognize the diversity of differences and cultural pluralism, both race, ethnicity, ethnicity, and religion. A concept that provides an understanding of the plurality of a nation is filled with diverse or multicultural cultures. A multicultural nation is a nation

\footnotetext{
${ }^{19}$ Roland C. Dolls, Curriculum Improvement Deciion Making and Process, (Ally Bacon: Boston. 1974), 24

${ }^{20}$ Choirul Mahfud, Pendidikan Multikultural, 75

${ }^{21}$ Ain al-Rafiq Dawam, Emoh Sekolah, (Yogyakarta: Inspeal Ahimsa Karya Press, 2003), 99-100.
}

consisting of ethnic or cultural groups that can coexist peacefully on the principle of co-existence, which is characterized by a willingness to respect other cultures. $^{22}$ Thus, multiculturalism recognizes the existence of cultural diversity and requires respect for each different culture.

Thus, the multicultural paradigm provides lessons to have an appreciation and aspect of other cultures and religions. On this basis, the application of multiculturalism requires selfawareness of each local culture to recognize and respect the diversity of cultural identities wrapped in the spirit of harmony and peace. ${ }^{23}$

Meanwhile, if the multicultural paradigm is brought about because of education, which then gives rise to the term multicultural education, it can be understood as education for people of color. That is, education in which there are types of humans or education that is shown to see human diversity or more than that education that tries to see and then responds to the reality of diversity that exists in humans, either individually or as social beings. So, multicultural education is an education related to human diversity.

More than that, multicultural education requires creating individuals who are aware of the existence of

22Nanih Mahendrawati dan Ahmad Syafe'i, Pengambangan Masyarakat Islam: dari Ideologi. Strategi Sampai Tradsi, (Bandung: Remaja Rosda Karya, 2001), 34.

23Salmawati, Urgensi Pendidikan Agama Islam dalam Pengembangan Nilai-nilai Multikultural, Junal al-Ta'lim (Vol. 20, No. 1, 2013), 337.

e-ISSN: 2715-4572

p-ISSN: 2716-1439 
cultural pluralism in which there are many differences and do not stop at awareness but can also respect the diversity that exists to create harmony and peace.

This multicultural education can be applied in a formal educational institution. Multicultural education does not only require the involvement of educators but all components in the institution must be directed at the concept of multicultural education. Multicultural education must also be related to educational policies that contain the values of democracy, justice, equality, and so on that reflect multicultural attitudes.

\section{Methodology}

This study uses a qualitative approach with the object of research is a government high school in Palu. In this study, the researchers took one of the government high schools to be the case of the study. The case was state senior high school six in Palu city.

We used a qualitative methods in this study with several considerations. First, the qualitative methods is helpful when dealing with multiple realities. ${ }^{24}$ Second, it can directly present the nature of the relationship between researchers and informants. ${ }^{25}$ Third, this method is

24 Nurdin, Nurdin. (2021). Employing Online and Offline Qualitative Interpretive Case Studies in Understanding E-Procurement Effectiveness. International Journal of Quantitative and Qualitative Research Methods, 9(1), 23-41.

${ }^{25}$ Nurdin, Nurdin, Stockdale, Rosemary, \& Scheepers, Helana. (2013). The Use of Social Media to Gather Qualitative Data: A Case of Government E-Procurement Implementation and more sensitive and adaptable to the many sharpening of the common direction and the patterns of values encountered. ${ }^{26}$

Data were collected using observation techniques, in-depth interviews with the school principla and teachers from the school, and data were also obtained from written documents. While the data analysis is done using reduction and verification techniques with various data sources. ${ }^{27}$ The reduced data is then analyzed by claiming to the theoretical concepts used in this study.

\section{Result and Discussion}

\subsection{Multicultural values in schools}

Based on the results of research in the field regarding the condition of multicultural values at State senior high schools Palu through interviews and observations with several informants who are considered competent and know about the problem being studied, in the explanation of the condition of multicultural values in schools, it shows the existence of multicultural values in the form of planting through lessons at school. This proves that based on the

Use. Paper presented at the 24th Australasian Conference on Information Systems (ACIS)

26Nurdin, Nurdin. (2018). Institutional Arrangements in E-Government Implementation and Use: A Case Study From Indonesian Local Government. International Journal of Electronic Government Research (IJEGR), 14(2), 44-63. doi: 10.4018/ijegr.2018040104

27 Nurdin, Nurdin, \& Aratusa, Zana Chobita. (2020). Benchmarking level interactivity of Indonesia government university websites. TELKOMNIKA Telecommunication, Computing, Electronics and Control, 18(2), 853-859.

e-ISSN: $2715-4572$

p-ISSN: 2716-1439 
author's observations in the field, the author finds students in schools who are religious from different backgrounds, namely Islam, Christianity, and Hinduism. However, with their religious differences, they work together, respect each other, tolerate, and are sincere in one another. So that inter-religious harmony at State senior high schools Palu is well and harmoniously established. ${ }^{28}$

All of the above, State senior high schools Palu always upholds and respects tolerance, respect, compassion, and as the implementation of an indicator that must be achieved by schools in instilling multicultural values in schools has been going well, although not optimally but has applied, in more detail the author describes as follows:

This inclusive (open) value recognizes the diversity of school community members, both religion, ethnicity, culture, and nation. This value recognizes pluralism in a community or social group and promises to put forward the principle of inclusiveness, which leads to the growth of sensitivity to the various possibilities.

Based on the results of field observations of inclusive values, in fact, students at State senior high schools Palu, always prioritize an open attitude and share stories and history related to a belief, ethnicity and culture that they believe in, such as every celebration of religious holidays among each other.

${ }^{28}$ Data hasil Observasi pada tanggal, 6 Juli 2018. Di SMA Negeri 6 Palu pro-active and supportive, with this a togetherness will be established. ${ }^{29}$

Social Reality Students at State senior high schools Palu have a variety of multicultural students who differ, for example, religion, ethnicity, and culture. However, so far, there has never been a conflict of SARA that has resulted in ethnic conflict. Through the cultivation of multicultural values, it will have a positive impact on the importance of the awareness process to students in the school environment about the meaning and nature of diverse multiculturalism.

The following are the results of an interview with Mrs. Inapisa as an Islamic religious education teacher who said the following: "...In this implementation, we as teachers in schools seek to inculcate these values to help develop an awareness of religious pluralism, especially to build mutual openness among students among one another, with the hope of making the basis for positive thinking acting, and interacting in the classroom. or at school well. 30

In line with the statement above, Mr. Amiruddin as an Islamic religion teacher, said as follows: "In the process of inculcating multicultural values, we always juxtapose some subjects in school, for example, Islamic religious education lessons. However, we are not only

${ }^{29}$ Data hasil Observasi pada tanggal, 6 Juli 2018. Di SMA Negeri 6 Palu.

${ }^{30}$ Inapisa, Guru Pendidikan Agama Islam SMA Negeri 6 Palu. “Wawancara”, Palu. 9 Juli 2018.

e-ISSN: $2715-4572$

p-ISSN: 2716-1439 
monotonous in learning activities in school, but we teach mutual respect in extracurricular activities in this school. From there, we teach them about mutual respect." 31

It can be seen that the cultivation of multicultural values at State senior high schools Palu can be channeled through several subjects using the right strategy from the teacher. However, at this level, the teacher also provides guidance on how to respect each other between ethnic groups, races, cultures, and religions to students through the process of extracurricular activities.

Based on the results of the observations and interviews above, it can be analyzed that inclusive values are a means of thinking awareness processes. Acting in interactions at school as a form of building social relations in schools, the awareness that has been built will be effective if through education because education is an instrument that is believed to have the most effective role in the process of internalizing multicultural values. So that by itself will grow an attitude of mutual respect and the highest respect for human dignity.

Based on the results of the observations and interviews above, it can be analyzed that inclusive values are a means of thinking awareness processes. Acting in interactions at school as a form of building social relations in schools, the awareness that has been built will be effective if through education because education is an instrument that is believed to have the most effective role in the process of internalizing multicultural values. So that itself will grow an attitude of mutual respect and the highest respect for human dignity.

This condition is a challenge for the world of education to be more oriented towards multicultural understanding. Schools that have a strategic role in inculcating multicultural values have a responsibility for these efforts. Through the teaching process, schools need to emphasize and instill that diversity as a nation's wealth deserves to be understood comprehensively.

The value of tolerance, tolerance living in the school environment can be understood as a manifestation of recognizing and respecting human rights. Freedom of belief in the sense of the absence of coercion in matters of religion, freedom of thought, or opinion it can be seen that the students in the celebration of religious activities actually support each other and even take a small part without any coercion due to differences in religion, ethnicity or culture.

Based on the results of the researcher's observations, that Islamic religious education teachers have sought to realize the values of tolerance, it can be seen in the teacher's efforts in the learning process, the teacher does not question the diversity or differences of students, so that learning goes on as usual by always upholding mutual

${ }^{31}$ Amiruddin, Guru Pendidikan Agama Islam SMA Negeri 6 Palu. "Wawancara”, Palu. 9 Juli 2018 
attitudes. respect and respect each other. $^{32}$

The value of helping, as social beings in the school environment, they realize the importance of a sense of help. This is proven when a friend of theirs is sick, and they always help their friend by taking them to the emergency room. The students action was considered as an emotional tied in the students relationships. ${ }^{33}$ As such, the emotional tiedness increased their well-being 34 which resulted in mutual respect among multicultural students.

In this regard, based on the results of the researcher's observations that the value of helping each other that develops in the school environment for the diversity that exists, namely that students can uphold this value, it can be seen when learning takes place between students actively helping each other in working together to complete the assigned group assignments. by subject teachers in class without seeing differences in religion, ethnicity or class. In addition, it can be seen during activities outside the classroom, namely in the school environment, socializing and playing together without

${ }^{32}$ Data hasil Obsetvasi di SMA Negeri 6 Palu. Pada tanggal 28 Agunstus 2018.

33 Askar, Askar, Adawiyah, Adawiyah, \& Nurdin, Nurdin. (2021). Understanding Students' Psychological Distress Complaints through Online Academic Advising Support. Medico Legal Update, 21(3), 162-167.

Nurdin, Nurdin. (2021). Understanding Women's Psychological Well-Being in PostNatural Disaster Recovery. Medico Legal Update, 21(3), 151-161. distinguishing between religious, ethnic, and cultural differences. ${ }^{35}$

In connection with the problem above, the researcher interviewed Drs. H. Tasrip Rantenei MM, as the principal, the results are as follows:

"In the school we teach, the students are quite diverse. However, we still have to be good at responding to differences in order to achieve unity. The school does not mind the difference, the activities in the school are always done together and help each other." 36

Based on the results of the interviews above, schools are always good at responding to differences, which is what is applied to students. Multicultural values are still applied to students in the learning process and in activities outside of school hours.

The value of justice (democratic) justice is a comprehensive term in all forms, whether justice gets the right to learn, cultural, political, and social. In fact, the attitude of justice itself is reflected in the students when they get what they need in the school environment, both the treatment of fellow students at school and in the classroom, and vice versa, the teachers at school do not differentiate between one student and another.

Based on the author's observations at State senior high schools Palu, the school has realized the value of justice that has developed in the school.

${ }^{35}$ Data hasil Observasi di SMA Negeri 6 Palu. Pada tanggal 31 Agustus 2018.

36Tasrip Rantenai, Guru Pendidikan Agama Islam SMA Negeri 6 Palu. "Wawancara", Palu. 1 September 2018

e-ISSN: $2715-4572$

p-ISSN: 2716-1439 
It is proven that the implementation can be seen in the diverse students, with the diversity that does not hinder their interaction between friends at school and between students. companions as usual without having to distinguish the difference. ${ }^{37}$

\subsection{Strategies of Islamic Religious Education Teachers in Instilling Multicultural Values}

Strategy is a pattern that becomes the primary reference before a learning activity takes place. It is necessary to prepare a complex framework as an element and component of learning. The use of strategies in learning is a determinant of the success of an activity. This is part of the media for students to achieve the desired goals. The effectiveness of a professional learning strategy is very dependent on the components presented by the teacher before the start of learning activities.

As an educational institution, State senior high schools Palu really appreciates these differences on the basis that religion is a belief for individuals. So that in the learning process, it goes as usual, what has been planned, we convey as it is, the lessons delivered are about giving examples of religious tolerance in everyday life.

To realize a multicultural-based school requires a strategy from a Islamic religious education teacher who acts as a facilitator in teaching, fostering, and guiding students to become

37Data hasil observasi di SMA Negeri 6 Palu. Pada tanggal 1 September 2018. knowledgeable human beings. ${ }^{38}$ Educators are an important factor in implementing multicultural values in schools. Because PAI teachers have an important position in multicultural value education, if a teacher has a moderate understanding of the diversity paradigm, he or she will also be able to teach and implement these diversity values to students in schools.

A teacher is required to seek the most appropriate and effective strategy in determining actions as an active response of students and reading the internal conditions of the school to adjust and see the basic abilities of students according to the planned predictions so that activities that take place are directed according to expectations.

From the facts above, the author describes in detail the strategies of Islamic religious education teachers and the stages, learning techniques, and methods as follows:

Learning activities contain two activities at once: learning activities carried out by students, and teaching activities carried out by teachers. In a learning process, there is interaction, some are taught, and some are taught. The learning process occurs is not an activity that occurs by chance and without a purpose but is carried out consciously that has been carefully planned to achieve certain goals.

${ }^{38}$ Rusli, Rusli, \& Nurdin, Nurdin. (2021). Understanding Indonesia millennia Ulama online knowledge acquisition and use in daily fatwa making habits. Education and Information Technologies. doi: 10.1007/s10639-021-10779-7 
Learning at the practical level is an activity composed of a combination of several elements that cannot be done arbitrarily. However, it must be systematically formulated and implemented based on existing principles. The clarity of the system and the effectiveness of each component are the main factors in determining the intensity of achieving the desired goals. Thus, it is rational if a strategy is needed in all activities related to teaching and learning activities, both at the planning stage of learning in the classroom as well as the act of assessing student learning outcomes.

The implementation of Islamic religious education learning strategies are methods of delivering Islamic religious education learning with multicultural values that were developed to make students able to respond and receive Islamic religious education lessons easily, quickly, and fun. From the research data, the strategies used by Islamic religious teachers at state senior high schools in Palu are quite varied.

In a good learning planning process, teachers need to make plans such as goals, materials, methods, and use of media related to learning Islamic religious education with multicultural values. Because every teacher has to make their own plans, In general, State senior high schools Palu plans the implementation of learning (RPP) made by Islamic religious education teachers, which have been formulated with careful consideration.

This can be seen from the preparation of long-term learning strategies and short-term learning strategies such as semester and annual programs. Moreover, the learning implementation plan (RPP) that has met the minimum standards and provisions set by the Provincial Educational Standard Agency.

At the time of the learning process, students listen to lectures and material related to multicultural values that need application, such as telling exemplary stories, learning is not only done in the classroom but students are also invited to learn to see and the environment. Surrounding social phenomena. Because in essence, a learning strategy that involves the teacher's active role as a facilitator will realize learning activities that can achieve the expected goals.

In this implementation, the efforts made by the teacher in determining the method or technique in delivering the message, determining the approach, media, and method of lesson content, as well as learning interactions with students. Because Islamic Religious Education learning is one of the subjects that is oriented towards fostering faith and piety and forming students with noble character, this implementation must be planned in such a way that in the implementation of learning, the message to be conveyed can be well received, internalized in students, and then become part of themselves to be practiced in everyday life.

Regarding the learning implementation plan (RPP) process at State senior high schools Palu, below are the results of an interview with $\mathrm{Mr}$. Amiruddin as a teacher of Islamic religious education, namely:

e-ISSN: $2715-4572$

p-ISSN: 2716-1439 
"The lesson plans have been made and are required to be owned by every teacher before carrying out the learning process. The lesson plans have been prepared well in advance with the demands that there must be and must have because this is a measurable reference in the delivery of the material being taught so that learning feels easy, directed based on the content of the lesson plan." 39

Based on the results of observations, Islamic religious education teachers, before starting learning, prepare lesson plans in advance. The readiness can see teachers who prepare lesson plans before starting learning, with a fairly mature application, can direct learning to centralized activities. Islamic Religious Education teachers are very important to design lesson plans before starting the learning process at school, and this has been supervised by the principal, all lesson plans that will be used before learning in class.

From the explanation above, it was found that the preparation of Islamic religious education teachers before the start of learning, by preparing the lesson plans first. The above are steps that must be taken before learning in class. So that the learning that will be presented can be directed to be better and more effective, and the teacher can easily control the teaching material that will be delivered to his students and achieve the desired learning.

${ }^{39}$ Amiruddin, Guru Pendidikan Agama Islam SMA Negeri 6 Palu. "Wawancara", Palu. 1 September 2018.
With sufficient preparation from a teacher, it is very important to make the learning process that has multicultural value-effective. Because the teacher before teaching must prepare everything related to the method being taught, the good and bad of the method applied will depend on the preparation of the teacher before teaching. The methods that will be delivered must be in accordance with the teaching materials that will be regulated in (RPP and syllabus).

The learning materials for each Islamic religious education teacher have been prepared and taken into account the characteristics and characteristics of the subject matter to be taught related to multicultural values. This means that there is an interaction between teachers and students in delivering teaching materials to students to achieve learning objectives in this implementation.

Learning strategies are efforts made by teachers in determining methods or techniques in delivering messages, determining approaches, media, and methods of lesson content, as well as learning interactions with students. Because Islamic religious education learning is one of the subjects that are oriented towards instilling faith and piety and forming students who have a noble character, it must be planned in such a way that in the implementation of learning, the message to be conveyed can be well received, internalized in students, then become part of themselves and to practice in everyday life. Islamic religious education teachers guide the implementation of Islamic religious education learning at State senior high

e-ISSN: 2715-4572

p-ISSN: 2716-1439 
schools Palu. With the allocation of time, there are 24 hours of lessons every week and 6 hours every day.

\section{Conclusion}

The strategy of Islamic religious education teachers in applying multicultural values is through improving learning in the classroom, meaning that Islamic religious education teachers utilize the learning process in the classroom by incorporating multicultural values into students through Islamic Religious Education subjects. Then through advice and guidance in schools, besides the Islamic Religious Education Teacher instilling multicultural values in the classroom, he also provides advice and guidance outside of learning hours. Students are required to say hello, tolerance, and various kinds of multicultural values.

\section{REFERENCES}

Abdullah Sulaiman, Belajar dan FaktorFaktor yang Mempengaruhinya, Jakarta: Rineka Cipta, 1991

Abdullah M., Pluralisme Agama dan Kerukunan Dalam Keagamaan, Jakarta: Buku Kompas 2001

Abdulrahman dkk, Profil Asosiasi Guru Pendidikan Agama Islam (AGPAII), Jakarta: NISRINA, 2009

Achmad Sauqi dan Ngainun Naim, Pendidikan Multikultural Konsep dan Amplikasi, Ar-Ruzz Media Yogyakarta: 2011

Ahmad Syafe'i dan Nanih Mahendrawati, Pengembangan Masyarakat Islam: Dari Ideologi.
Strategi Sampai Tradisi, Bandung: Remaja Rosdakarya, 2001

Al-fandi Haryanto, Desain Pembelajaran yang Demokratis dan humanis, ArRuzz Media, Yogyakarta: 2011.

Aswan Zaid dan Djamarah Syaiful Bahri, Strategi Belajar mengajar, Rineka Cipta: 2010

AGPAII, dkk, Panduan Integrasi Nilai Multikulutaral dalam Pendidikan Agama Islam Pada SMA dan SMK, (Jakarta: KIRANA CAKRA BUANA

Amiruddin, Amiruddin, Nurdin, Nurdin, \& Ali, Moh. (2021). Islamic Education Teacher Communication Strategy in Increasing Students' Learning Interest. International Journal of Contemporary Islamic Education, 3(1), 41-61.

Askar, Askar, Adawiyah, Adawiyah, \& Nurdin, Nurdin. (2021). Understanding Students' Psychological Distress Complaints through Online Academic Advising Support. Medico Legal Update, 21(3), 162167.

Azanuddin, Pengembangan Budaya Toleransi Beragama Melalui Pembelajaran Pendidikan Agama Islam (PAI) Berbasis Multikultural di SMA Negeri 1 Amlapura bali, Malang: PPS UIN Malang, 2010

Aly Abdullah, Pendidikan Islam Multikultural di Pesantren: Telaah Terhadap Kurikulum Pondok Pesantren Moderen Islam Assalam Surakarta, Cet I; Yogyakarta: Pustaka Pelajar, 2011 
Askar, Integrasi Keilmuan: Paradigma Pendidikan Islam Integratif Holistik, Bandung, Batic Press: 2011

Daradjat Zakiya Dkk, Ilmu Pendidikan Islam, Cet. VI; Bumi Aksara, Jakarta: 2006

Daradjat Zakiyah, Pendidikan Islam dalam Keluarga dan Sekolah, Ruhana, Jakarta: 1995

Dawam Ain al-Rafiq, Emoh Sekolah, Yogyakarta: Inspeal Ahimsa Karya Press, 2003

Departemen Pendidikan Nasional, Kamus Besar Bahasa Indonesia Jakarta:Rajawali Pers, 2014

Departement Kebuyaan dan Pariwisata, Pendidikan Multikulturak dan Revitalisasi Hukum Adat dalam Perspektif Sejarah, Kementrian Kebudayaan dan Pariwisata Deputi Bidang Sejarah dan Purbakala, Jakarta: 2005

Departemen Agama RI, al-Quran dan Tafsir: Edisi yang Disempurnakan Jilid II, Jakarta: Departemen Agama RI, 2010

Djamarah Syaifui Bahri, Guru dan Anak dalam Interaksi Edukatif, Rineka Cipta, Jakarta: 2000

Fathurrohman Pupuh, Strategi Belajar Mengajar Melalui Penanaman Konsep Umum dan Islam, Revika Aditama, Bandung: 2009

Hakiemah Ainun, Nilai dann Konsep Pendidikan Multikultural dalam Pendidikan Islam, Yogyakarta: PPS IAIN Sunan Kalijaga, 2007

Hamalik Oemar, Proses Belajar Mengajar PT. Bumi Aksara, Jakarta: 2004

Handayani, Andi Muthia Sari, \& Nurdin, Nurdin. (2021). Understanding Women's
Psychological Well-Being in PostNatural Disaster Recovery. Medico Legal Update, 21(3), 151-161.

Hardini Isriani, Strategi Pembelajaran Terpadu: Teori, Konsep dan Implementasi, Familiya, Group Relasi Inti Media: 2012

Idi Abdullah, Sosiologi Pendidikan: Individu, Masyarakat dan

Pendidikan Jakarta: Raja Grafindo Persada, 2011

Kusmariani Rosita Endang, Pendidikan Multikultural sebagai Alternatif Penanaman Nilai Moral dalam Keberagaman. Jurnal Paradigma, edisi 2 Tahun 2006

Lestari Dwi Puji, Model Pembelajaran Pendidikan Agama Islam Berbasia Multikultural SMAN 1 Wonosari Gunung Kidul, PPS Uin Sunan Kalijaga, 2012

Ma'arif Syamsul, Pendidikan Pluralisme di Indonesia, Yogyakarta: Logung Pustaka, 2005

Majid Abd., Belajar dan Pembelajaran Pendidikan Agama Islam, Bandung: Remaja Rosdakarya, 2012

Mahfud Choirul, Pendidikann Multikultural, Yogyakarta: Pustaka Pelajar, 2010

Majid Abdul, Perencanaan Pembelajaran, Remaja Rosada Karya, Bandung: 2006

Maksum Ali, Pluralisme dan Multikulturalisme: Paradigma Baru Pendidikan Islam di Indonesia, Malang: Aditya Media Publishing, 2011

Margono S., Metode Penelitian Pendidikan, Cet. II; Jakarta: Rineka Cipta, 2000 Manisya Sitti , Implementasi Pendidikan Multikultural dalam Pembelajaran. e-ISSN: $2715-4572$ p-ISSN: 2716-1439 
Jurnal Lentera Pendidikan edisi 13 Tahun 2010

Muhaimin, Rekronstruksi Pendidikan Islam, Raja Grafindo Persada, Jakarta: 2009

Muhaimin, Wacana Pengembangan Pendidikan Islam, Pustaka Pelajar, Yogyakarta: 2003

Muhaimin, Paradigma Pendidikan Islam: Upaya Mengefektifkan Pendidikan Islam Di Sekolah, Rosdakarya, Bandung: 2002

Mulyadi, Evaluasi Pendidikan (Pengembangan model Evaluasi Pendidikan Agama di Sekolah), UIN Maliki Press, Malang: 2010

Nasution S., Metode Research (Penelitian Ilmiah), Usul Tesis, Desain Penelitian, Hipotesis, Validitas, Sampling, Populasi, Obeservasi, Wawancara, Angket, Jakarta: Bumi Aksara, 2011

Noor Juliansyah, Metodologi Penelitian: Skripsi, Tesis, Disertasi, dan Karya ilmiah, Cet. IV; Jakarta: Kencana 2014

Nurdin, Nurdin, Stockdale, Rosemary, \& Scheepers, Helana. (2013). The Use of Social Media to Gather Qualitative Data: A Case of Government EProcurement Implementation and Use. Paper presented at the 24th Australasian Conference on Information Systems (ACIS)

Nurdin, Nurdin. (2018). Institutional Arrangements in E-Government Implementation and Use: A Case Study From Indonesian Local Government. International Journal of Electronic Government Research
(IJEGR), 14(2), 44-63. doi: 10.4018/ijegr.2018040104

Nurdin, Nurdin, \& Aratusa, Zana Chobita. (2020). Benchmarking level interactivity of Indonesia government university websites. TELKOMNIKA Telecommunication, Computing, Electronics and Control, 18(2), 853-859.

Nurdin, Nurdin. (2021). Employing Online and Offline Qualitative Interpretive Case Studies in Understanding E-Procurement Effectiveness. International Journal of Quantitative and Qualitative Research Methods, 9(1), 23-41.

Nuryatno M. Agus, Mazhab Pendidikan Kritis Menyikap Pengetahuan, Politik dan kekuasaan (Resist Book, Yogyakarta: 2008

Pribadi, Mohammad, \& Nurdin, Nurdin. (2021). The Practice of Salawat Nariyah in Rural Javanese Society Indonesia: Religiosity or Sociality? Review of International Geographical Education Online, 11(5), 2545-2555.

Prinato, Model-model Pembalajaran Inovatif Berorientasi Kontruktivistik, Perstasi Pustaka, Jakarta: 2011

Ramayulis, Ilmu Pendidikan Islam, Kalam Mulia, Jakarta: 2010.

Rusli, Rusli, \& Nurdin, Nurdin. (2021). Understanding Indonesia millennia Ulama online knowledge acquisition and use in daily fatwa making habits. Education and Information Technologies. doi: 10.1007/s10639021-10779-7 
Rusli, Rusli. (2009). Gagasan Khaled Abu Fadl tentang "Islam Moderat" versus "Islam Puritan" (Perspektif Sosiologi Pengetahuan). Jurnal Ilmiah Ilmu Ushuluddin, 8(1), 99-123.

Rusli, Rusli. (2014). Teaching Usul alFiqh: A Multicultural Education Model. Al-Tahrir: Jurnal Pemikiran Islam, 14(2), 447-464.

Rusli, Rusli. (2020). The Role of Family in Preventing Social Conflict in Society From Islamic Perspectives. HUNAFA: Jurnal Studia Islamika, 17(1), 108-122.

Salmiwati, Urgensi Pendidikan Agama Islam Dalam Pengembangan NilaiNilai Multikultural, Jurnal alTa'lim, Vol. 20, No. 1, 2013

Sugiyono, Memahami Penelitian Kualitatif, Cet. XIX; Bandung: Alfabeta, 2014

SM Ismail, Trategi pembelajaran PAI berbasis PAIKEM Rasail, Semarang: 2009

Suparlan, Menjadi Guru Efektif, Yogyakarta: Hikayat publishing, 2005

Supriadie Didi, Komunikasi Pembelajaran PT. Remaja RosdaKarya, Bandung: 2012

Syah Muhibbin, Psikologi Pendidikan Dengan Pendekatan Baru, Remaja Rosdakarya, Bandung: 2008

Syah Muhibbin, Psikologi Pendidikan Dengan Pendekatan Baru, Bandung: Remaja Rosdakarya, 2010

Tabrani Rusyan dan Cece Wijaya, Kemampuan Dasar Guru dalam Proses Belajar Mengajar, Remaja Rosda Karya, Bandung: 1994
Tim Pustaka Al-Kautsar, Mushaf alQuran dan Terjemahannya Jakarta: Pustaka Al-Kautsar, 2009

Tillman Diane, Pendidikan Nilai Untuk Kaum Muda Dewasa, Jakarta: Grafindo 2004

Tilaar H.A.R, Kekuasaan dan Pendidikan (Indonesia Tera, Magelang: 2003

Usman M. Uzer, Menjadi Guru Profesional, Remaja Rosda Karya, Bandung: 2010

Yasin A. Fatah, Dimensi-dimensi Pendidikan Islam, Malang: UIN Malang Press, 2008

Yaqin Ainul, Pendidikan Multikultural Cross-cultural Understanding Untuk Demokrasi dan Keadilan Pilar Media, Yogyakarta: 2005

Yudi Hartono dan H.A.Dardi Hasyim, Pendidikan Multikultural DI Sekolah, Surakarta: UPT Penerbitan dan Percetakan UNS, 2009 